\title{
Abnormal Vision
}

National Cancer Institute

\section{Source}

National Cancer Institute. Abnormal Vision. NCI Thesaurus. Code C118760.

Disturbance of eyesight. 